\title{
GENOTYPIC CHARACTERIZATION OF A Trueperella pyogenes STRAIN AS A MAJOR CAUSATIVE AGENT OF METRITIS, ABORTION AND DEATH IN Bubalus bubalis
}

\author{
Iradj Ashrafi Tamai', Abdolmajid Mohammadzadeh"* ${ }^{1 *}$,Taghi Zahraei Salehi², Pezhman Mahmoodi ${ }^{1}$ \\ ${ }^{1}$ Department of Pathobiology, Faculty of Veterinary Science, Bu-Ali Sina University, Hamedan, Iran, ${ }^{2}$ Department of Microbiology and \\ Immunology, Faculty of Veterinary Medicine, University of Tehran, Tehran, Iran
}

*Corresponding author, E-mail:mohammadzadeh4@gmail.com; mohammadzadeh@basu.ac.ir

\begin{abstract}
Trueperella pyogenes is a species of commensal bacteria which is present on the upper respiratory, urogenital and gastrointestinal mucosae of cattle. This species is able to cause pyogenic infections and health risks, alone or in association with other pyogenic bacteria. However, systemic disease with abortion and death in water buffalo has not yet been documented. Here, we isolated a strain of T. pyogenes, from a pregnant water buffalo (Bubalus bubalis) with metritis and pneumonia, which finally caused abortion and death in the affected host. Thereafter, the virulence genes and antibiotic resistance of the isolate were investigated. Single PCR method confirmed the presence of the well-known virulence genes of $T$. pyogenes including plo, nanH, nanP, $c b p A$, fimA, fimC, fimE and fim G genes. Antibiotic susceptibility test revealed that this isolate was resistant against Tetracycline, Erythromycin and Trimethoprim sulfamethoxazole. Furthermore, using Box-PCR method, it was determined that DNA fingerprint pattern of this isolate was different from that of a control strain (T. pyogenes ATCC 19411). The results of the present study indicated that T. pyogenes can cause a systemic lethal disease in water buffalo. However, it seems that host and environmental conditions may also contribute to such infection. To our knowledge, this is the first report of a buffalo with pneumonia, metritis, abortion and death caused by T. pyogenes.
\end{abstract}

Key words: Trueperella pyogenes; Bubalus bubalis; buffalo; BOXPCR; abortion, death

\section{Introduction}

Trueperella pyogenes which is formerly known as Actinomyces pyogenes and Arcanobacterium pyogenes, has recently been reclassified based on distinctive $16 \mathrm{~S}$ rRNA gene sequences. This bacterium is an irregular, non-motile, non-sporeforming, aerobic, commensal, Gram-positive coccobacillus which is normally isolated from the upper respiratory, urogenital and gastrointestinal tracts $(1,2,3)$. It is proposed as a worldwide

Received:2January 2018

Accepted for publication:24 December 2019 distributed secondary pathogen which may cause disease conditions such as acute and summer mastitis, metritis, clinical and subclinical endometritis, cutaneous and visceral abscesses, arthritis, pneumonia, endocarditis, osteomyelitis and several other suppurative infectious diseases in a broad range of domestic and wild animals including cattle, swine, sheep, goat, camel, buffalo, deer, antelope, reptiles and also birds (3, 4). T. pyogenes is closely associated with other pyogenic bacteria such as E.coli, Streptococcus dysgalactiae and Fusobacterium necrophorum and this can increase its constant presence in pyogenic bacterial infections and resistance 
against antimicrobial agents (5). T. pyogenes not only causes pyogenic infections and health risks, mostly in cattle, but also greatly affects economy of animal husbandry by drastic reduction in lactation and fertility of cattle which results in culling of these animals or removal of involved organs, mainly liver and lung, at slaughter houses (6). Moreover, its probable pathogenicity for human, especially in immunosuppressed and diabetic patients, and the role of consumption of dairy products in public health, further highlights the importance of $T$. pyogenes $(7,8)$.

Several pathogenic properties are known in $T$. pyogenes which can increase its pathogenicity $(2,3)$. Pyolysin $(p l o)$, as one of its major virulence factors, causes hemolysis and cytolysis of leukocytes. This hemolysin attaches to the cell membrane cholesterol and lyses the cells by generating pores in the cell membrane. It also plays a role in cytokines expression and tissue damages. On the other hand, bacterial adhesion to epithelial cells, colonization as well as degradation of DNA and sialic acid, are attributed to $\mathrm{H}$ and $P$ neuraminidases (nanH and nanP) of this bacterium. Furthermore, these neuraminidases block phagocytosis of bacterial cells by increasing membrane viscosity (2). Different types of fimbriae are expressed by $T$. pyogenes including A, G, E and $C$ (9). These types of fimbriae are required for adherence to membranes and epithelial cells. Collagen and fibronectin-binding proteins ( $\mathrm{Cbp}$, $F b p$ ) are essential for adhesion to collagen-rich tissues (types 1, 2, 4) and fibronectins. In addition, the protease and DNase of T. pyogenes provides nutrients for the bacteria through degradation of proteins and nucleic acids (3).

Antibiotic therapy is a common treatment in metritis. Consequently, overuse of antibiotics as treatment or as preventive and growth inhibitor agents has caused development of resistance to several antibiotics in $T$. pyogenes $(10,11,12)$. Therefore, antimicrobial susceptibility tests along with molecular determination of antibiotic resistance genes can facilitate selecting appropriate antibiotics. The aim of this study was to determine the virulence characterizations and antibiotic resistance genes in a primary pathogenic $T$. pyogenes strain, causing abortion and death in a water buffalo (Bubalus bubalis), and determining whether bacterial colonies isolated from aborted fetus and different organs of infected $B$. bubalis are identical. This study was the first of its kind carried out in Iran to examine these specific virulence and antibiotic resistance genes.

\section{Materials and methods}

\section{Sampling}

Sampling was conducted at multiple times during June 2017 from a pregnant buffalo with metritis and abundant pyogenic discharges. Clinical signs including tachycardia, tachypnea, anorexia, fever and weakness were observed in the animal. Abortion occurred two days after the first sampling; hence, a set of samples was also collected from cotyledons, abomasum and fetal fluids. Necropsy was performed one day later, since the buffalo died from the disease. Extensive abscesses were observed in internal organs, particularly in liver and lung (Figure 1). All samples were collected in individual sterile containers, in ice packed coolers, and sent to the bacteriology laboratory for further culturing and identification of potential infectious agents.

\section{Bacterial isolation and growth conditions}

Following preparation of smears from all specimens, they were cultured on blood agar supplemented with 5\% sheep blood and MacConkey agar (Merck, Germany) and incubated at $37{ }^{\circ} \mathrm{C}$ for $48 \mathrm{~h}$ under $5-10 \% \mathrm{CO}_{2}$. Gram-stained smears of all plated isolates were also prepared. To identify the bacteria, several biochemical tests including catalase, oxidase, urease and CAMP tests, nitrate reduction, gelatin hydrolysis, esculin hydrolysis, litmus milk, pitting of Loeffler serum, and fermentation of glucose, lactose, maltose, mannitol, sucrose and xylose were performed on isolates (13).

\section{Antimicrobial susceptibility test}

Antibiotic sensitivity was tested by KirbyBauer disk diffusion method. Susceptibility of samples was tested against routine medicine and veterinary medicine antibiotics on Mueller Hinton agar (Merck, Germany) supplemented with 5\% sheep blood. All isolates were screened for their resistance profile against Gentamicin (GM $120 \mu \mathrm{g}$ ), Ampicillin (AP $25 \mu \mathrm{g}$ ), Penicillin G (PG 10 units), 
Enrofloxacin (ENF $5 \mu \mathrm{g}$ ), Tetracycline (TE $30 \mu \mathrm{g}$ ), Amoxicillin (A $25 \mu \mathrm{g}$ ), Spectinomycin (SPC 100 $\mu \mathrm{g})$, Trimethoprim sulfamethoxazole (TS $25 \mu \mathrm{g}$ ), Erythromycin (E $15 \mu \mathrm{g})$, Ciprofloxacin (CIP $5 \mu \mathrm{g}$ ), Cefalexin (CFX $30 \mu \mathrm{g})$, according to the guidelines of the Clinical and Laboratory Standards Institute (CLSI) (14). Results were read after $48-72 \mathrm{~h}$ of incubation.

\section{$D N A$ extraction and polymerase chain reac- tion (PCR)}

Isolated bacteria were cultured in TSB broth (Merck, Germany) supplemented with $5 \%$ bovine serum and incubated at $37^{\circ} \mathrm{C}$ for $48 \mathrm{~h}$. Thereafter, $3 \mathrm{ml}$ of TSB broth was centrifuged at $10,000 \mathrm{~g}$ for $10 \mathrm{~min}$ at $4{ }^{\circ} \mathrm{C}$. The pellet was washed once with saline solution. Finally, genomic DNA was extracted using a commercial DNA extraction kit for Gram-positive bacteria according to the manufacturer's instruction (MBST, Iran). The extracted DNA samples were stored at $-20{ }^{\circ} \mathrm{C}$. To identify $T$. pyogenes, a PCR assay was performed which targeted 16S-23S rDNA intergenic spacer region in genomic DNA (15). PCR was done in $25 \mu \mathrm{l}$ of a reaction mixture containing 12.5 $\mu 1$ of $2 \mathrm{X}$ Master mix (BIONEER Cat. No. PCR106S-CSTM), $0.1 \mu \mathrm{l}$ of each primer (100 pmol), (F:
5'- GTTTTGCTTGTGATCGTGGTGGTTATGA-3', R: 5'- AAGCAGGCCCACGCGCAGG- 3') (BIONEER, Korea), $3 \mu 1$ of template DNA and $7.5 \mu 1$ of distilled water. The reaction was carried out in a thermocycler (TC-512 Techne, England) as follows; an initial denaturation at $95{ }^{\circ} \mathrm{C}$ for $10 \mathrm{~min}$, then 30 cycles of $95{ }^{\circ} \mathrm{C}$ for $30 \mathrm{sec}, 64^{\circ} \mathrm{C}$ for $15 \mathrm{sec}$, $72{ }^{\circ} \mathrm{C}$ for $30 \mathrm{sec}$ and a final extension at $72{ }^{\circ} \mathrm{C}$ for $7 \mathrm{~min}$. The amplification products $(5 \mu \mathrm{l})$ were resolved by electrophoresis on $1.5 \%$ agarose gel in $1 \mathrm{x}$ TBE for $1 \mathrm{~h}$ at $100 \mathrm{~V}$. Afterwards, the agarose gel was stained with $1 \mu \mathrm{g} / \mathrm{ml}$ ethidium bromide (CinnaGen, Cat No. MR7721C) and screened using UV-illuminator (BIORAD, UK).

\section{Screening of genes encoding virulence factors}

Single PCR method was used to evaluate the presence of known $T$. pyogenes virulence genes including plo, nanH, nanP, $\operatorname{cbp} A$, fimA, fimC, fimE and fim $G$ in the isolates $(16,5)$. Each PCR assay was performed in a reaction mixture with the final volume of $20 \mu \mathrm{l}$ containing $10 \mu \mathrm{l}$ of $2 \mathrm{X}$ Master Mix, $0.1 \mathrm{pmol}$ of each of forward and reverse primers (100 pmol), $2 \mu \mathrm{l}$ of template DNA and $6 \mu \mathrm{l}$ of distilled water. The sequence of primers and PCR conditions are presented in table 1 .

Table 1: Oligonucletide primer sequences and PCR conditions

\begin{tabular}{|c|c|c|c|}
\hline Virulence factor / Target gene & Primer sequence $\left(5^{`}-3^{`}\right)$ & Amplicon size $(\mathrm{bp})$ & Annealing $\left({ }^{\circ} \mathrm{C}\right)$ \\
\hline Pyolysin (plo) & $\begin{array}{l}\text { F: TCATCAACAATCCACGAAGAG } \\
\text { R: TTGCCTCCAGTTGACGCTTT }\end{array}$ & 150 & 60 \\
\hline Neuraminidase $\mathrm{H}$ (nanH) & $\begin{array}{l}\text { F: CGCTAGTGCTGTAGCGTTGTTAAGT } \\
\text { R: CCGAGGAGTTTTGACTGACTTTGT }\end{array}$ & 781 & 60 \\
\hline Neuraminidase $\mathrm{P}$ (nanP) & $\begin{array}{l}\text { F: TTGAGCGTACGCAGCTCTTC } \\
\text { R: CCACGAAATCGGCCTTATTG }\end{array}$ & 150 & 60 \\
\hline Collagen-binding protein $(c b p A)$ & $\begin{array}{l}\text { F: GCAGGGTTGGTGAAAGAGTTTACT } \\
\text { R: GCTTGATATAACCTTCAGAATTTGCA }\end{array}$ & 124 & 60 \\
\hline Type A fimbria (fimA) & $\begin{array}{l}\text { F: CACTACGCTCACCATTCACAAG } \\
\text { R: GCTGTAATCCGCTTTGTCTGTG }\end{array}$ & 605 & 57 \\
\hline Type G fimbria (fimG) & $\begin{array}{l}\text { F: ACGCTTCAGAAGGTCACCAGG } \\
\text { R: ATCTTGATCTGCCCCCATGCG }\end{array}$ & 929 & 57 \\
\hline Type E fimbria (fimE) & $\begin{array}{l}\text { F: GCCCAGGACCGAGAGCCAGGGC } \\
\text { R: GCCTTCACAAATAACAGCAACC }\end{array}$ & 775 & 55 \\
\hline Type C fimbria (fimC) & $\begin{array}{l}\text { F: TGTCGAAGGTGACGTTCTTCG } \\
\text { R: CAAGGTCACCGAGACTGCTGG }\end{array}$ & 843 & 60 \\
\hline
\end{tabular}




\section{Genotyping}

Using BOX-PCR, DNA fingerprints of the isolates were obtained to determine the relationships among them $(17,18)$. All of the isolates obtained from metritis, cotyledon of the aborted fetus and abscesses in the liver and lung of the buffalo (after necropsy). Genomic DNA of the control strain of $T$. pyogenes and distilled water were used in BOX-PCR as positive and negative controls, respectively. BOX-A1R primer (5'-CTACGGCAAGGCGACGCTGACG- 3') was used for amplification. PCR mixture was prepared using $12.5 \mu \mathrm{l}$ of $2 \mathrm{X}$ Master Mix, $0.2 \mathrm{pmol}$ of the primer $(100 \mathrm{pmol} / \mu \mathrm{l}), 1 \mu \mathrm{l}$ of template DNA (100 ng) and $9.5 \mu$ of distilled water in a final volume of $25 \mu 1$. The reaction was carried out as follows; an initial denaturation at $95{ }^{\circ} \mathrm{C}$ for $2 \mathrm{~min}$, then 34 cycles of $95{ }^{\circ} \mathrm{C}$ for $1 \mathrm{~min}, 53{ }^{\circ} \mathrm{C}$ for $1 \mathrm{~min} 72$ ${ }^{\circ} \mathrm{C}$ for $5 \mathrm{~min}$ and a final extension at $72{ }^{\circ} \mathrm{C}$ for $10 \mathrm{~min}$. The amplification products $(5 \mu \mathrm{l})$ were resolved by electrophoresis on $1.5 \%$ agarose gel for $3 \mathrm{~h}$ at $70 \mathrm{~V}$. Afterwards, the agarose gel was stained with ethidium bromide and screened using UV-illuminator. Similarities and differences between amplified fragments were analyzed using NTSYSpc software (version 2.1, USA).

\section{Results}

\section{Culturing and biochemical tests}

Small, irregular Gram-positive coccobacilli were observed in smears obtained from the organs. After 48 h, small white colonies with fine complete hemolysis were detected on the blood agar plates, but no growth was observed on the MacConkey agar plates. Smears from cultured colonies also contained irregular Gram-positive coccobacilli. Catalase, oxidase, urease, nitrate reduction and esculin tests were negative for all isolates. On the contrary, the results of gelatin hydrolysis and pitting of Loeffler serum were positive. In litmus milk, production of acid, curd, reduction and protein digestion were observed. The isolates fermented lactose, sucrose, xylose and maltose; however, none of them fermented mannitol. CAMP test with Staphylococcus aureus was also positive.

\section{Antimicrobial susceptibility test}

The results revealed that all of the isolates were sensitive to Ampicillin, Penicillin G, Amoxicillin, Spectinomycin, Cefalexin and Ciprofloxacin. By contrast, they were resistant against Tetracycline, Erythromycin and Trimethoprim sulfamethoxazole. Susceptibility grade of the isolates against Enrofloxacin and Gentamicin was intermediate.

\section{S-23S rDNA PCR}

As shown in figure 2, DNA fragment of expected size (122 bp) was observed for all of the isolates obtained from metritis, cotyledon, liver and lung; therefore, it was confirmed that all of them were T. pyogenes. No DNA band was amplified from the negative control.

\section{Genes encoding virulence factors}

DNA fragments corresponding to the sequences of investigated virulence genes including plo, nanH, nanP, $c b p A$, fimA, fimC, fimE and fimG were successfully amplified from the extracted DNA samples of all isolates. The results of these PCR assays are depicted in figure 3.

\section{Box PCR}

Eight different bands of about 300, 550, 600, 650, 700, 800, 1000 and $1200 \mathrm{bp}$ compared with $1 \mathrm{~kb}$ standard ladder (CinnaGen Cat No. PR 901645) were observed for all of the isolates (Figure 4). As illustrated in figure 5, an identical DNA fingerprint pattern was detected for all of the isolates, suggesting that they were the same strain. However, this pattern was completely different in comparison to that obtained from the control strain of $T$. pyogenes.

\section{Discussion}

Over the past decades, T. pyogenes has been known as an opportunist suppurative pathogen in domestic animals (19). A wide range of studies have been done on this microorganism which showed it can affect a large group of hosts and causes multiple diseases in different organs and a geographic region (3). Mastitis, metritis, pyometra, umbilicitis, lymphadenitis, prostatitis, 

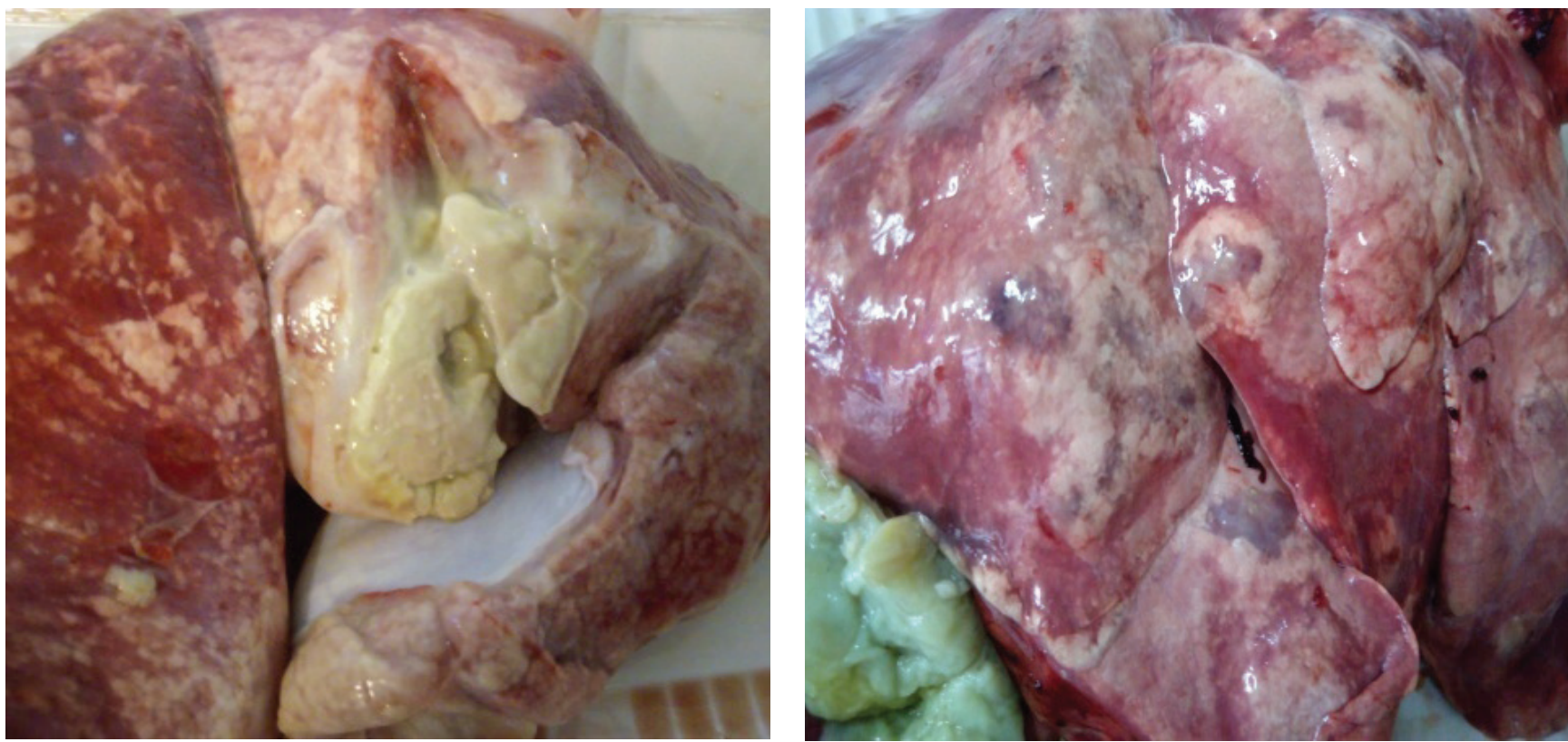

Figure 1: Necropsy findings; diffusive abscesses and pyogenic lesion in liver and lung

Figure 2: 16S- 23S rDNA- ISR PCR. Lane 1. PCR product using distilled water as negative control. Lane 2-5: PCR product of DNA from bacteria isolates in this study, Lane 6. PCR product of DNA from ATCC 19411 T. pyogenes strain as positive control, Lane L. $100 \mathrm{bp}$ ladder DNA marker
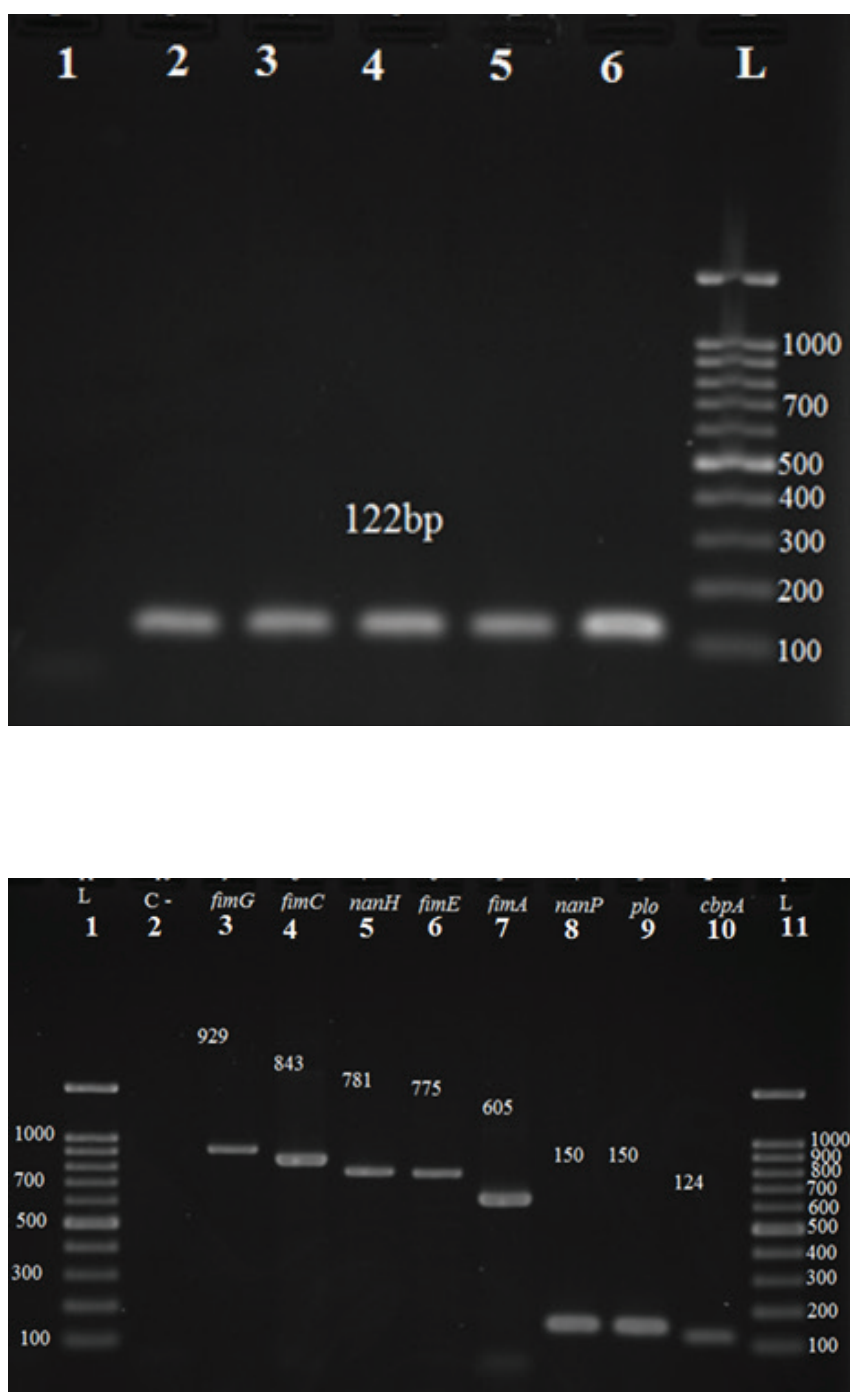

Figure 3: Single PCR for genes encoding virulence factors in T. pyogenes. Lane 1: 100 bp ladder DNA marker, Lane 2. PCR product using distilled water as negative control, Lane 3-10. PCR products of DNA from a T. pyogenes isolate in this study with specific primers for plo, nanH, nanP, cbpA, fimA, fimC, fimE and fimG genes. Lane 11: $1 \mathrm{~kb}$ ladder DNA marker 

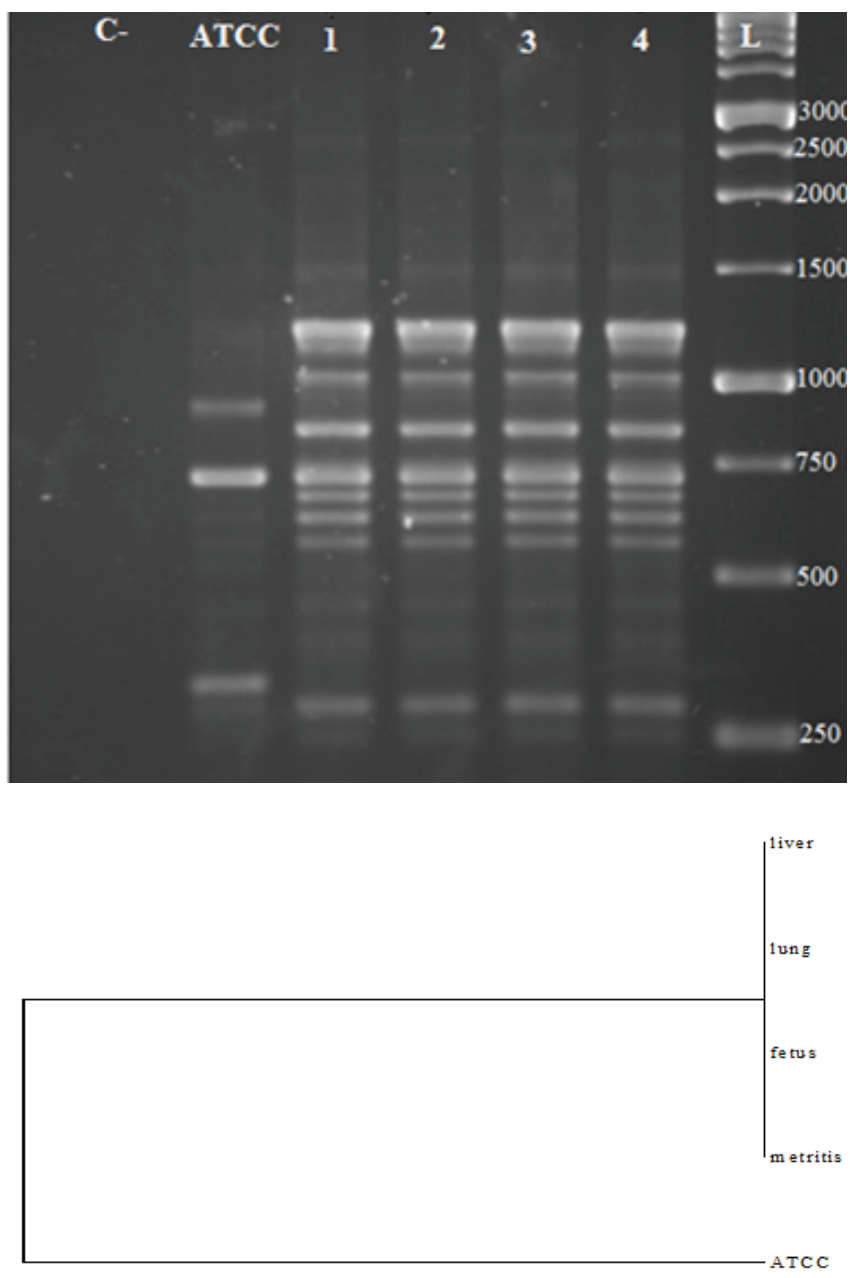

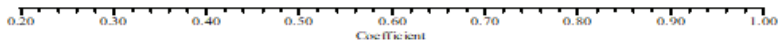

orchiditis, pericarditis, encephalitis, septicemia and other pyogenic infections are described as the most important clinical complications caused by $T$. pyogenes in cattle; among which, mastitis, metritis and pneumonia are the most common forms $(2,19)$. According to literature, pneumonia is a common complication since cold, stress and poor housing conditions underlie this condition in the infected animals (20). The case of infectious pneumonia reported in this study came as a surprise, since pneumonia is reported in ruminants most commonly during warm season. Probably, poor housing conditions, noise from constructions around the stable and pregnancy induced additional stress in the studied animal, and promoted $T$. pyogenes pneumonia. In addition to the effects of these factors, several other elements such as food and water deprivation, mix livestock farming, transport, management and feeding quality have been proposed as the main
Figure 4: Box-PCR fingerprinting, Eight different bands with molecular weights of 300, 550, 600, 650, 700, 800, 1000,1100 and $1200 \mathrm{bp}$ compared with $1 \mathrm{~kb}$ standard ladder Lane $\mathrm{L}$ ) were observed in isolates from metritis in the buffalo, cotyledon of aborted fetus and abscesses in liver and lung (Lane 1-4). A T. pyogenes strain used as positive control had a different composition of bands (Lane ATCC 19411)

Figure 5: Dendrograms of clonal relationship based on BOX PCR by NTSYSpc (version 2.10e)

predisposing factors for $T$. pyogenes infections (21). Clinical implications of pyogenic bacteria such as mastitis and abscess formation in organs have a large impact on the herd economy and result in a huge loss of revenue in livestock. T. pyogenes may be responsible for direct economic losses due to condemnation of carcasses or different organs, particularly liver and lung $(22,23,24,25,26)$.

Metritis caused by $T$. pyogenes after parturition is highly prevalent in cattle. Moreover, other pathogenic bacteria such as E.coli and Fusobacterium necrophorum commonly increase the severity of this infection (5). However, pure cultures of $T$. pyogenes derived from metritis were documented in this study during the pregnancy and before the parturition. These results indicated that $T$. pyogenes, as a member of gut flora, could also be proposed as a primary pathogen causing diseases in different organs of the host (3). All of the isolates in this study were identified using 
morphological and biochemical tests. Although, biochemical and phenotypical tests are typically used to identify $T$. pyogenes, variation in characteristics of this bacterium may cause some difficulties in this process $(27,11)$. Magdalena et al. identified 14 biotypes of $T$. pyogenes, among which, some showed weak and others, strong hemolytic reactions by CAMP test (28). However, only one biotype was detected and verified by a recent highly valuable molecular method in the present study. Ashrafi Tamai et. al. eight different biotypes were identified among the isolates based on the phenotypical properties such as hemolysis, CAMP and biochemical analysis (11). Although cephalosporins, tetracycline, penicillins and some other beta-lactam antimicrobial agents are considered as the antibiotics of choice for $T$. pyogenes infections, recently antimicrobial resistance against some of these agents have been detected (3). T. pyogenes isolates identified in this study were sensitive to ampicillin, penicillin G, amoxicillin, spectinomycin, and ciprofloxacin, whereas they were resistant against tetracycline, erythromycin and trimethoprim sulfamethoxazole. In a similar study, (85.5\%) and (9.1\%) resistance to tetracycline and erythromycin were reported, respectively (29). In another study, the highest resistance was observed against trimethoprim sulfametoxazol $(49.3 \%$ and $72.3 \%)$ followed by norfloxacin (10.9\% and 17\%) and tetracycline $(9.2 \%$ and $10.8 \%)(20,11)$. Indeed, excessive use of antimicrobial agents leads to antibiotic resistance in $T$. pyogenes infections. Besides, intensive administration of tetracycline and macrolides in veterinary medicine as feed additives with preventive or growth inhibitor purposes has resulted in antibiotic resistance of $T$. pyogenes $(20,11)$. Although some antibiotics are effective against isolates under laboratory conditions, they are not able to diffuse into the center of granulomatous lesions in progressive stages of the disease, which complicates the treatment of $T$. pyogenes infections (19). Therefore, late diagnosis and improper choice of antibiotics are associated with a poor prognosis. Additionally, antibiotic resistance is a great concern in medical administration of antibiotics in humans.

T. pyogenes expresses 8 different virulence genes which play crucial roles in its pathogenic properties (3). In the present study, plo, nanH, nanP $\operatorname{cbp}$ A, fimA, fimC, fimG and fimE virulence genes were detected in all of the isolates. One of the most important virulence genes is pyolysin (plo), an extracellular toxin, which is one of the first pathogenic factors detected in $T$. pyogenes (3). Although pyolosin was primarily identified as a hemolysin of red blood cells in a variety of animal species, its cytolytic effect has been demonstrated in several different host cells such as polymorphonuclear leukocytes (PMNS) and macrophages $(30,3)$. Several studies have reported that all $T$. pyogenes strains encode pyolsin gene but the frequency of its expression is higher in pathogenic strains involved in clinical complications $(31,32,33)$. Neuraminidases, encoding by nanH and nanP genes, are two other main virulence factors of $T$. pyogenes. Neuraminidase or sialidase is an extracellular enzyme which cleaves sialic acid residue from carbohydrates and glycoproteins to be used as a carbon source of energy by bacteria (34). Neuraminidase has a major role in adhesion of bacteria to the epithelial cells, particularly the resident bacteria of mucosal membranes (35, $36,37)$. Collagen, as the most abundant protein in mammalians, is one of the main adhesion targets for a large number of bacteria (38). $T$. pyogenes also has the ability to attach to collagen through expression of collagen-binding protein $(c b p A)$. Mutant strains of Trueperella which are unable to express $\operatorname{cbp} A$ show reduced adhesion to HeLa and 3T6 cells, whereas normal strains of T. pyogenes display higher adhesion qualities. Therefore, $\operatorname{cbp} A$ is considered as an important pathogenic factor required for adhesion and colonization of T. pyogenes to collagen-rich tissues (38). Fimbriae were determined in T. pyogenes for the first time by Jost and Billington in 2005 (2). Fimbriae of T. pyogenes, like other bacteria, promote the adhesion of this microorganism to the host tissues (9). In a study performed by Silva and others in 2008, 8 virulence factor-encoding genes were detected in $T$. pyogenes isolates including 4 fimbrial subtypes. In that study, fimA, fimE and both fimC and fimG were encoded, respectively, in $100 \%, 98 \%$ and $67 \%$ of isolates (16). In fact, the abundance of genes encoding fimbrial subtypes including fimA, fimC, fimG and fimE varies among different strains of $T$. pyogenes. Although, these virulence genes are encoded in both clinical and commensal $T$. pyogenes isolates, the difference is in the frequency of these genes in pathogenic conditions (3). For instance, in a study carried out by Santos in 2010 and ashrafi Tamai in 2017, a 
higher frequency of $T$. pyogenes fimA gene was recorded in strains isolated from metritic cows in comparison to normal puerperium cows, indicating the importance of this gene in the adhesion of $T$. pyogenes and its pathogenesis $(10,11)$. In another study done by Bradely and others in 2015, all $T$. pyogenes isolated from cranial abscesses of male white-tailed deer encoded fimA, plo and nanP. However, fimE, fim G, fimC and nanH were only detected in $70 \%$ of those isolates and $c b p$ had the lowest rate of expression (38). Magdalena and others in 2012 detected plo and fimA in all T. pyogenes isolated from Bison bonasus and they found that fim G, fimC, cbp, nanP and nanH were respectively encoded in $24 \%, 88 \%, 12 \%, 44 \%$ and $40 \%$ of the isolates (39). Ashraffi Tamai et.al. in 2017 detected plo and fimA, in all T. pyogenes isolated from cattle with clinical metritis and they found that nanH, nanP, fimG, fimC, fimE and $c b p$ were respectively encoded in $83.1 \%, 76.9 \%, 61.5 \%$, $69.2 \%, 76.9 \%$ and $56.9 \%$ of the isolates (11). Another aim of the present study was to determine the association between $T$. pyogenes strains isolated from different tissues and the aborted fetus. According to the result of Box PCR assay, all of the T. pyogenes isolates were clustered into one group while the control strain was in another cluster suggesting that all of the isolates were the same strain. Considering similar characteristics and virulence genes profiles of the isolates, it can be assumed that Trueperella pyogenes was the major causing pathogen in the described case.

In the current study, we discussed that although $T$. pyogenes is considered as a normal floral bacterium in various organs of domestic animals and the presence of virulence factors is not enough for its pathogenicity, it can turn into a primary pathogen depending on the host status and environmental conditions, and consequently, cause several complications including metritis, abortion and finally death in water buffalo (Bubalus bubalis). The genome sequence of this strain has been deposited in the GenBank database under the accession number CP028833.

\section{Acknowledgements}

The authors declare no conflicts of interest.

This project emanates from Ph.D. thesis of the first author and was financially supported by research grants from Bu-Ali Sina University of Hamedan. The authors would like to thank Mottaghian P. for help in sample collection.

\section{References}

1. Yassin AF, Hupfer H, Siering C, Schumann P. Comparative chemotaxonomic and phylogenetic studies on the genus Arcanobacterium Collins et al. 1982 emend. Lehnen et al. 2006: proposal for Trueperella gen. nov. and emended description of the genus Arcanobacterium. Int J Syst Evol Microbiol 2011; 61: 1265-74.

2. Jost BH, Billington SJ. Arcanobacterium pyogenes: molecular pathogenesis of an animal opportunist. Antonie Van Leeuwenhoek 2005; 88: 87-102.

3. Rzewuska M, Kwiecień E, Chrobak-Chmiel D, Kizerwetter-Świda M, Stefańska I, Gieryńska M. Pathogenicity and virulence of Trueperella pyogenes: a review. Int J Mol Sci 2019; 20(11): e2737. doi: 10.3390/ijms20112737

4. Rogovskyy AS, Lawhon S, Kuczmanski K, et al. Phenotypic and genotypic characteristics of Trueperella pyogenes isolated from ruminants. J Vet Diagn Invest 2018; 30: 348-53.

5. Bicalho ML, Machado VS, Oikonomou G, Gilbert RO, Bicalho RC. Association between virulence factors of Escherichia coli, Fusobacterium necrophorum and Arcanobacterium pyogenes and uterine diseases of dairy cows. Vet Microbiol 2012; 157: 125-31.

6. Moore R, Miyoshi A, Pacheco LGC, Seyffert N, Azevedo V. Corynebacterium and Arcanobacterium. In: Gyles CL, Prescott JF, Songer JG, Theone CO, eds. Pathogenesis of bacterial infections in animals. 4th ed. Ames : Wiley Blackwell, 2010: 113-47.

7. Gahrn HB, Frederiksen W. Human infections with Actinomyces pyogenes (Corynebacterium pyogenes). Diagn Microbiol Infect Dis 1992; 15: 349-54.

8. Plamondon M, Martinez G, Raynal L, Touchette M, Valiquette L. A fatal case of Arcanobacterium pyogenes endocarditis in a man with no identified animal contact: case report and review of the literature. Eur J Clin Microbiol Infect Dis 2007; 26: 663-6.

9. Liu M, Wang B, Liang $\mathrm{H}$, Ma B, Wang J, Zhang W. Determination of the expression of three fimbrial subunit proteins in cultured Trueperella pyogenes. Acta Vet Scand 2018; 60: e53.

doi: 10.1186/s13028-018-0407-3 
10. Santos TMA, Caixeta LS, Machado VS, Rauf AK, Gilbert RO, Bicalho RC. Antimicrobial resistance and presence of virulence factor genes in Arcanobacterium pyogenes isolated from the uterus of postpartum dairy cows. Vet Microbiol 2010; 145: 84-9.

11. AshrafiTamai I, Mohammadzadeh A, ZahraeiSalehi T, Mahmoodi P. Genomic characterisation, detection of genes encoding virulence factors and evaluation of antibiotic resistance of Trueperella pyogenes isolated from cattle with clinical metritis. Antonie Van Leeuwenhoek 2018; 111: 2441-53.

12. Feßler AT, Schwarz S. Antimicrobial resistance in Corynebacterium spp., Arcanobacterium spp., and Trueperella pyogenes. Microbiol Spectr 2017; 5(6). doi: 10.1128/microbiolspec.ARBA0021-2017

13. Al-Saggaf MS, Al-Ssum RM, Shair OMS. Isolation and identification of Arcanobacterium pyogenes (Actinomyces pyogenes) from Arabian gazelles. Afr J Biotechnol 2011; 10: 18614-31.

14. NCCLS Performance standards for antimicrobial susceptibility testing. 11th Informational Supplement, CLSI/NCCLS document M100-S11. Wayne, Pensylvania : National Committee for Clinical Laboratory Standards, 2001.

15. Ulbegi Mohyla H, Hijazin M, Alber J, et al. Identification of Arcanobacterium pyogenes isolated by post mortem examinations of a bearded dragon and a gecko by phenotypic and genotypic properties. J Vet Sci 2010; 11: 265-7.

16. Silva E, Gaivao M, Leitao S, et al. Genomic characterization of Arcanobacterium pyogenes isolates recovered from the uterus of dairy cows with normal puerperium or clinical metritis. Vet Microbiol 2008; 132: 111-8.

17. Martin B, Humbert O, Camara M, et al. A highly conserved repeated DNA element located in the chromosome of Streptococcus pneumoniae. Nucl Acid Res 1992; 20: 3479-83.

18. Louws FJ, Fulbright DW, Stephens CT, de Bruijn FJ. Specific genomic fingerprints of phytopathogenic Xanthomonas and Pseudomonas pathovars and strains generated with repetitive sequences and PCR. Appl Environ Microbiol 1994; 60: 2286-95.

19. Quinn PJ, Markey BK, Leonard FC, Fitzpatrick ES, Fanning S, Hartigan PJ. Veterinary microbiology and microbial disease. $2^{\text {nd }}$ ed. Oxford : Wiley Blackwell, 2011: 245-57.

20. Ribeiro MG, Risseti RM, Bolaños CAD, et al. Trueperella pyogenes multispecies infections in domestic animals: a retrospective study of 144 cases (2002 to 2012). Vet Q 2015; 35: 82-7.

21. Kasimanickam VR, Owen K, Kasimanickam RK. Detection of genes encoding multidrug resistance and biofilm virulence factor in uterine pathogenic bacteria in postpartum dairy cows. Theriogenology 2015; 30: 1-7.

22. Jensen R, Flint JC, Griner LA. Experimental hepatic necrobacillosis in beef cattle. J Am Vet Res 1954; 15: 5-14.

23. Nagaraja TG, Laudert SB, Parrott JC. Liver abscesses in feedlot cattle. Part I: causes, pathogenesis, pathology, and diagnosis. Compend Contin Educ Pract Vet 1996; 18: 230-41.

24. Nagaraja TG, Laudert SB, Parrott JC. Liver abscesses in feedlot cattle. Part IL Incidence, economic importance, and prevention. Compend Contin Educ Pract Vet 1996; 18: 264-73.

25. Narayanan S, Nagaraja TG, Staats J, Chengappa MM, Oberst RD. Biochemical and biological characterizations and ribotyping of Actinomyces pyogenes and Actinomyces pyogenes-like organisms from liver abscesses in cattle. Vet Microbiol 1998; 61: 289-303.

26. Narayanan S, Nagaraja TG, Wallace N, Staats J, Chengappa MM, Oberst RD. Biochemical and ribotypic comparison of Actinomyces pyogenes and $A$. pyogenes-like organisms from liver abscesses, ruminal wall, andruminal contents of cattle. J Am Vet Res 1998; 59: 271-6.

27. Hijazin M, Ulbegi-Mohyla H, Alber J, et al. Molecular identification and further characterization of Arcanobacterium pyogenes isolated from bovine mastitis and from various other origins. J Dairy Sci 2011; 94: 1813-9.

28. Rzewuska M, Stefańska I, Osińska B, et al. Phenotypic characteristics and virulence genotypes of Trueperella (Arcanobacterium) pyogenes strains isolated from European bison (Bison bonasus). Vet Microbiol 2012; 160: 69-76.

29. Zastempowska E, Lassa H, Genotypic characterization and evaluation of an antibiotic resistance of Trueperella pyogenas (Arcanobacterium pyogenes) isolated from milk of dairy cows with clinical mastitis. Vet Microbiol 2012; 161: 153-8.

30. Funke G, Ramos CP, Fernández-Garayzábal JF, Weiss N, Collins MD. Description of human-derived centers for disease control Coryneform group 2 bacteria as Actinomyces bernardiae spp. Int J Syst Bacteriol 1995; 45: 57-60.

31. Ding H, Lämmler C. Purification and fur- 
ther characterization of a haemolysin of Actinomyces pyogenes. J Vet Med 1996; 43: 179-88.

32. Billington SJ, Jost BH, Cuevas WA, Bright KR, Songer JG. The Arcanobacterium (Actinomyces) pyogenes hemolysin, pyolysin, is a novel member of the thiolactivated cytolysin family. J Bacteriol 1997; 179: 6100-6.

33. Jost BH, Songer JG, Billington SJ. An Arcanobacterium (Actinomyces) pyogenes mutant deficient in production of the poreforming cytolysin pyolysin has reduced virulence. Infect Immun 1999; 67: 1723-8.

34. Gottschalk A, Bhargava AS. Neuraminidases. In: Boyer PD, ed. The enzymes. $3^{\text {ed }}$, Vol. 5. New York : Academic Press, 1971: 321-42.

35. Galen JE, Ketley JM, Fasano A, Richardson SH, Wasserman SS, Kaper JB. Role of Vibrio cholerae neuraminidase in the function of cholera toxin. Infect Immun 1992, 60: 406-15.
36. Giebink GS. Otitis media: the chinchilla model. Microbial Drug Resist 1999; 5: 57-72.

37. Tong HH, Blue LE, James MA, DeMaria TF. Evaluation of the virulence of a Streptococcus pneumoniae neuraminidase-deficient mutant in nasopharyngeal colonization and development of otitis media in the chinchilla model. Infect Immun 2000; 68: 921-4.

38. Esmay PA, Billington SJ, Link MA, Songer JG, Jost BH. The Arcanobacterium pyogenes collagen-binding protein, $C b p A$, promotes adhesion to host cells. Infect Immun 2003; 71: 4368-74.

39. Bradley SC, Emily HB, Shamus Pk, Michael JY, Karl VM. Isolation and genotypic characterization of Trueperella (Arcanobacterium) Pyogenes recovered from active cranial abscess infections of male white tailed deer (Odocoileus Virginianus). J Zoo Wildl Med 2015; 46: 62-7.

\title{
DOLOČITEV GENOTIPA SEVA Trueperella pyogenes KOT GLAVNEGA POVZROČITELJA VNETJA MATERNICE, SPLAVOV IN SMRTI PRI VODNIH BIVOLIH (Bubalus bubalis)
}

\author{
I. A. Tamai, A. Mohammadzadeh, T.Z. Salehi, P. Mahmoodi
}

Povzetek: Trueperella pyogenes je vrsta komenzalnih bakterij, ki je prisotna v sluznicah zgornjih dihal, urogenitalnega trakta in sluznicah prebavil pri govedu. Ta vrsta lahko samostojno ali v povezavi z drugimi vnetnimi bakterijami povzroči vnetja in ogroža zdravje. Sistemska oblika bolezni s splavom in smrtjo pri vodnih bivolih še ni bila dokumentirana. Pri samici vodnega bivola (Bubalus bubalis) z vnetjem maternice in pljučnico smo izolirali sev T. pyogenes, ki je povzročil splav in smrt prizadete živali. Raziskali smo virulenčne gene in njihovo odpornost proti antibiotikom. Z metodo PCR smo potrdili prisotnost dobro znanih virulenčnih genov T. pyogenes, vključno s plo, nanH, nanP, cbpA, fimA, fimC, fimE in fimG geni. Preizkus občutljivosti na antibiotike je pokazal, da je bil ta izolat odporen proti tetraciklinu, eritromicinu in trimetoprim sulfametoksazolu. Poleg tega smo z metodo Box-PCR ugotovili, da se vzorec DNK tega izolata razlikuje od vzorca kontrolnega seva (T. pyogenes ATCC 19411). Rezultati študije so pokazali, da lahko T. pyogenes povzroči sistemsko smrtonosno bolezen pri vodnih bivolih, vendar gostiteljski in okoljski pogoji pomebno vplivajo na razvoj okužbe. Kolikorvemo, je to prvo poročilo o bivolih s pljučnico, vnetjem maternice, splavom in smrtjo, kijihje povzročil T.pyogenes.

KIjučne besede: Trueperella pyogenes; Bubalus bubalis; bivol; BOXPCR; splav; smrt 